Marquette University

e-Publications@Marquette

Marketing Faculty Research and Publications

Marketing, Department of

9-1-2009

\title{
Applying Catholic Social Teachings to Ethical Issues in Marketing
}

Thomas A. Klein

University of Toledo

Gene R. Laczniak

Marquette University, eugene.laczniak@marquette.edu

Accepted version. Journal of Macromarketing, Vol. 29, No. 3 (September 2009): 233-243. DOI. (C) 2009 SAGE Publications. Used with permission. 


\title{
Applying Catholic Social Teachings to Ethical Issues in Marketing
}

\author{
Thomas A. Klein \\ University of Toledo \\ Toledo, $\mathrm{OH}$ \\ Gene R. Laczniak \\ Marquette University \\ Milwaukee, WI
}

\begin{abstract}
:
This article updates earlier work by the authors and proposes the social teachings of the Roman Catholic Church to be an encompassing and coherent normative theory, a source of principles that address contemporary issues in marketing, especially when a manager faces ethically charged questions. The authors propose that this application of a tradition in moral theology offers a novel approach for helping resolve contemporary ethical problems in marketing. Their approach to this task pursues two paths. First, the main tenets of Catholic social teaching are presented, along with some discussion of sources. Then, some of the ethical issues associated with contemporary marketing are introduced. These two paths are joined together by connecting Catholic social teaching principles to these questions. Finally, they argue for the value of this approach outside the framework of any denominational or sectarian context.
\end{abstract}

Keywords: Catholic social thought Catholic social teaching distributive justice ethics in markets marketing ethics.

This article updates and extends earlier work by the authors (e.g., Klein 1987; Laczniak 1998, 1999) and proposes the social teachings of the Roman Catholic Church1 as an encompassing and coherent normative theory, a source of principles for addressing

Journal of Macromarketing, Vol 29, No. 3 (September 2009): pg. 233-243. DOI. This article is C SAGE Publications and permission has been granted for this version to appear in e-Publications@Marquette. SAGE Publications does not grant permission for this article to be further copied/distributed or hosted elsewhere without the express permission from SAGE Publications. 
contemporary ethical issues in marketing. The approach to this task is twofold. First, the main tenets of Catholic social teaching (CST) are presented, along with some discussion of sources. Then, some of the ethical issues associated with contemporary marketing are discussed. These two paths are linked together by applying CST principles to these questions. Finally, the authors argue for the advantage of this approach independent of its connection to any religious doctrine. That is, they contend that the principles of CST are valuable as normative ethical guidelines regardless of their denominational roots, in part, because they can also be derived from nonsectarian philosophical theory, that is, this particular religious perspective and other perspectives converge in addressing problems of contemporary importance.

In a very real sense, CST can be positioned as an unusual interpretive method for the exploration of macromarketing issues, because even with its own religious tradition, it has been characterized by experts as "our best kept secret" (DeBerri et al. 2003). Moreover, rather than being used (as one might casually suspect) to underscore a particular set of religious values, the discussion that follows offers CST as a blended, principle-based social philosophy that provides a scope of pragmatic guidance for managers and marketing analysts that exceeds that of many other moral frameworks (see discussion of CST principles below). Finally, while CST has a long history associated with its development (as recounted in this article), its application to marketing issues has been limited despite its promise for surprisingly nuanced insight and interpretation of ethical questions pervasive in marketing practice and systems. In sum, CST applied to marketing issues is a superb example of how something old and somewhat ignored can provide a novel approach to solving thorny contemporary problems.

Some introductory comments will lay a foundation for this exposition. CST is the sum total of lessons from scripture (including the Ten Commandments as well as passages from both the Old and the New Testament of the Bible), papal encyclicals and other Vatican writings, documents prepared by Church Commissions, and letters from national conferences of bishops as applied to social concerns. In a broader sense, CST also includes the analyses of theologians,

Journal of Macromarketing, Vol 29, No. 3 (September 2009): pg. 233-243. DOI. This article is (C) SAGE Publications and permission has been granted for this version to appear in e-Publications@Marquette. SAGE Publications does not grant permission for this article to be further copied/distributed or hosted elsewhere without the express permission from SAGE Publications. 
philosophers, and subject matter experts (e.g., economists and political scientists) attempting to relate these lessons to particular problems, times, and places.

CST has been applied to a variety of social issues (e.g., the role of the family unit in society and the concept of a "just" war), but the authors' major concern here is its application to business practice, particularly questions having marketing dimensions. Notable in this regard, because they are examples of Vatican interest in specific marketing problems having ethical dimensions, are two reports issued by the Pontifical Council on Social Communications (a unit within the Roman Curia, the Vatican bureaucracy), Ethics in advertising (1997), and Ethics in Internet (2002). It should also be pointed out that these CST lessons have both diagnostic and prescriptive content. In other words, CST addresses how a problem arises as well as what might be done about it that is in keeping with religious teachings. Of additional interest is the fact that CST has both micro and macro implications. That is, CST admonishes individuals and firms to adhere to its values, but it also suggests (seldom specifying in detail) general public policy approaches for correcting deficiencies in the social and economic systems that influence processes and outcomes at odds with those values.

The late Pope John Paul II $(1987,1991)$ was especially prolific in advancing CST with regard to recent social concerns. A complete enumeration of CST theory can also be found in Compendium of the social doctrine of the church (2005) issued by the US Conference of Catholic Bishops. An abbreviated version of CST is available from a 1999 publication of the National Conference of (US) Catholic Bishops, Sharing Catholic Social Teaching: Challenges and Directions. The focus of that latter work is on seven major issues, which can serve as the authors' organizing platform for the enduring themes of CST: (1) life and dignity of the human person, (2) call to family, community, and participation, (3) rights and responsibilities, (4) option for the poor and vulnerable, (5) dignity of work and the rights of workers, (6) solidarity (across national, racial, and other differences or boundaries), and (7) care for God's creation.

From each of these seven themes, guiding principles have been derived based on citations to the religious root sources referenced

Journal of Macromarketing, Vol 29, No. 3 (September 2009): pg. 233-243. DOI. This article is C SAGE Publications and permission has been granted for this version to appear in e-Publications@Marquette. SAGE Publications does not grant permission for this article to be further copied/distributed or hosted elsewhere without the express permission from SAGE Publications. 
above (Compendium 2005). The CST tradition conceives of these principles as connective and integrative. That is, beginning with the core principle of "human dignity," each principle can be used to increase one's understanding of the others. Altogether, they constitute a "moral theology" or a religion-based ethics for business, but also (as the authors shall contend) an approach to business ethics that can be seen as a blended moral philosophy entirely compatible with secular reasoning and parallel, nonsectarian derivation (Compendium 2005, 34). As they set forth the various principles of CST most relevant to marketing issues, their compatibility to lines of reasoning in secular, moral philosophy and business ethics are also briefly noted.

\section{Key Principles of Catholic Social Teaching}

\section{The Principle of Human Dignity}

The most basic and fundamental instruction of CST flows from the idea that all persons ("created in the image of God") have inherent worth regardless of race, color, or creed. Dignity is not "earned" but rather it is always a given right to be accorded to all persons in all circumstances. This principle is used to argue that "The economy exists for the person, not the person for the economy" (National Conference of Catholic Bishops 1996 [1]) and that an excessive focus on profit maximization can be harmful to authentic personal development because rewards and burdens may not be justly distributed (Compendium 2005 [279]). Evaluated on its own, this principle also is suggestive of Kant's (1787) categorical imperative (second formulation), which reminds that people should never be used as a means merely for some (economic) end.

\section{The Principle of the Common Good}

This principle flows partly from the above noted theme \#2 and its "call to family, community, and participation" of everyone in the benefits of the commonwealth. From it unfolds the CST doctrine of the "universal destination of goods" (Compendium 2005 [282]). This implies that the goods of the earth should be used for the benefit of all, not exclusively from an economic perspective, but from a balanced social, cultural, and community standpoint. While CST clearly affirms the right of private property, this teaching provides a foundation for

Journal of Macromarketing, Vol 29, No. 3 (September 2009): pg. 233-243. DOI. This article is C SAGE Publications and permission has been granted for this version to appear in e-Publications@Marquette. SAGE Publications does not grant permission for this article to be further copied/distributed or hosted elsewhere without the express permission from SAGE Publications. 
the notion that "all persons have the right to secure the basic necessities of life." Included here would not only be the right of all persons to food, shelter, and available work but also access to education and affordable health care (Pope John XXIII 1963 [11]). This principle recalls elements of the (multicultural and nondenominational) United Nations' Universal Declaration of Human Rights (1948).

\section{The Principle of Subsidiarity}

This is one of the most basic articulations of rights and responsibilities inherent in CST. It states "It is an injustice ... to assign to a greater or higher association what lesser and subordinate organizations can do" (Pope Pius XI 1931 [79]). It grants that everyone, as they are able, needs to contribute as well as receive from the community: "If able, all people have ... a ... duty to work and provide for their families" (National Conference of Catholic Bishops 1997 [6]). Commentators on this principle also imply that the concept warns about the dangers of overregulating business activities and, indeed, such an argument can be sustained. However, the same principle is also used in CST to insure that sufficiently powerful parties weigh in to offset persistently unfair practices in society: "Society has a moral obligation, including governmental action where necessary, to assure opportunity, meet basic human needs, and pursue justice in economic life" (National Conference of Catholic Bishops 1997 [8]). While respectful of the idea that the work of commerce in the society is undertaken by the private sector with private property and rewards, this principle underscores the "integrative social contracts" implication that businesses collectively must operate in the public interest (Donaldson and Dunfee 1999).

\section{The Principle of Preference for the Poor and Vulnerable}

This teaching recalls the Gospel admonitions of Jesus to "Love thy neighbor" and "What you do for the least of my brethren, you do for me." Here, CST argues that "the proper end of economic activity is the progress of the entire community, especially the poor" (Massaro 2005). This centrality of the obligation to help the poor is manifest not only in CST but also in every other major religious doctrine-Jewish, Protestant, Islamic, Hindu, and Buddhist. Holding a mandated

Journal of Macromarketing, Vol 29, No. 3 (September 2009): pg. 233-243. DOI. This article is (C SAGE Publications and permission has been granted for this version to appear in e-Publications@Marquette. SAGE Publications does not grant permission for this article to be further copied/distributed or hosted elsewhere without the express permission from SAGE Publications. 
obligation to aid the impoverished is also consistent with the secular theory of "justice as fairness" articulated in the writings of philosopher John Rawls (1971). In particular, the Rawlsian "difference principle" seeks that changes in social policies be evaluated in terms of how they affect those least well off. Therefore, actions that benefit those better off at the expense of the poorest are "unjust." The "first face" duty of beneficence-the obligation of those with more resources to help as they are able, as argued in the (secular) moral intuitionism of philosopher William David Ross (1930)-also comes to mind in conjunction with this teaching.

\section{The Principle of Worker Rights}

This theme advances the idea that work is central to human growth and that workers help to continue the wonder of God's creation. This is the oldest teaching of modern CST dicta, embodied in the encyclical of Pope Leo XIII, Rerum Novarum, published in 1891, and elaborated in Laborem Exercens by Pope John Paul II (1981). These documents proclaim: "All people have the right to economic initiative, to productive work, to just wages and benefits, to decent working conditions as well as to organize and join unions or other associations" (National Conference of Catholic Bishops 1997 [5]). They grant workers the right to organize in unions and suggest that duties of past loyalties by workers always need to be recognized. "Any business that does not enhance its workers and serve the common good is a moral failure no matter how healthy the bottom line" (DeBerri et al. 2003).

This principle also calls to mind the business framework of "stakeholder theory" and its specification of employees as central stakeholders to any corporate enterprise (Freeman 1984; Freeman, Harrison, and Wicks 2007). In recognizing this parallel, the authors stipulate that the stakeholder concept may be invoked as merely "good business"-taking account of stakeholder interests helps advance the interests of the firm in attracting and retaining employees as well as customers, suppliers, and so on, that is, in improved productivity, reduced costs, and increased sales and profits. This approach also provides a more encompassing and fundamental understanding of the sources of business success than the alternative "shareholder theory" in which owner interests alone are decision Journal of Macromarketing, Vol 29, No. 3 (September 2009): pg. 233-243. DOI. This article is (C SAGE Publications and permission has been granted for this version to appear in e-Publications@Marquette. SAGE Publications does not grant permission for this article to be further copied/distributed or hosted elsewhere without the express permission from SAGE Publications. 
criteria. Whatever the merits of that understanding, the authors' perspective is that serving the interests of employees recognizes claims that may transcend both legal obligations and business interests. This principle is also supported by the perspective of "the common good" (Naughton, Alford, and Brady 1995).

\section{The Principle of Solidarity}

This concept recognizes that all people and social groups are united in a brotherhood that seeks common growth and fulfillment, in the debt of one another for the support that the authors require in community. It provides a framework for the idea that " ... economic life should be shaped by moral principles" (National Conference of Catholic Bishops 1997 [2]) because all persons both seek and want a fair opportunity to attain betterment in their lives. This foundational theme of CST is the basis for advocating ethical responsibilities of rich nations to poor as well as the special ethical obligations of multinational businesses operating in developing countries (Tavis 1999). Further reflection on this principle evokes the classical notion of virtue ethics, whereby individuals seek to contribute their part to the creation of a "moral community" (Aristotle 1985) and to cultivate "strength of character" to donate to the common good of an expanding community (MacIntyre 2007).

\section{The Principle of Stewardship}

This precept captures the responsibility of every partyincluding corporations - to contribute to the care of the earth. It is among the newest in the evolution of CST. It calls for economic actions always to "respect the integrity and cycles of nature" and to fastidiously avoid environmental exploitation (Compendium 2005 [470]). It views the physical environment as a common pool of abundant resources not to be exploited for the benefit of only a few or at the expense of future generations. It connects to the "green ethic" and the "sustainability criterion" so prominent in current competitive strategy discussions (Elkington 1998). However, it must be noted that this principle stops short of endorsing the Gaia Hypothesis (Lovelock 1979), which, in effect, deifies nature. In CST, nature is man's garden, to be protected and enriched as an instrument of humanity but not given autonomous status.

Journal of Macromarketing, Vol 29, No. 3 (September 2009): pg. 233-243. DOI. This article is (C) SAGE Publications and permission has been granted for this version to appear in e-Publications@Marquette. SAGE Publications does not grant permission for this article to be further copied/distributed or hosted elsewhere without the express permission from SAGE Publications. 
NOT THE PUBLISHED VERSION; this is the author's final, peer-reviewed manuscript. The published version may be accessed by following the link in the citation at the bottom of the page.

\section{Discussion of Principles}

Considered together, these principles represent a blended moral theory that provides guidance for managers and policy makers seeking insights when they encounter "tough" ethical questions stemming from marketing situations. The authors characterize CST as "blended" because it addresses intent, duties, and outcomes-the full spectrum of ethical analysis and, when looked at independently from its doctrinal anchoring, seems consistent with a variety of secular moral philosophies.

But why should a non-Catholic marketing manager pay any attention whatsoever to CST? At least two responses to this question seem to merit consideration. One has to do with how the majority of managers respond when asked from what source they derive their ethical values. The most common answer is their religion (McMahon 1989). The second response, hinted at above, relates to how the various principles of CST can also be reconciled with those advocated by the major thinkers in moral philosophy-Aristotle, Kant, Ross, Rawls, and so on. In other words, CST reflects thinking that parallels a variety of ethical perspectives enshrined in moral philosophy that are also applicable to business situations that raise social questions.

While the pertinence of the principles discussed above to marketing issues varies, all have some implications for marketing practice. One may also detect in these themes strands of thought that might apply to well-understood secular questions about distributive justice in marketing: Do the poor pay more? Are vulnerable markets such as children and immigrants sufficiently protected? Are suppliers or distributors treated fairly when they are the distinctly less powerful channel members?

These CST themes also can be connected to macro discussions such as the ideal construction of market exchange systems (How "free" vs. "regulated" should various markets be?) and technology use (i.e., its mandate to facilitate human advancement while, at the same time, avoiding exploitation). For instance, in marketing, specific examples of technological exploitation occur when customer databases are sold without patron permission or when hidden cameras are used to observe consumer behavior without notification.

Journal of Macromarketing, Vol 29, No. 3 (September 2009): pg. 233-243. DOI. This article is C SAGE Publications and permission has been granted for this version to appear in e-Publications@Marquette. SAGE Publications does not grant permission for this article to be further copied/distributed or hosted elsewhere without the express permission from SAGE Publications. 


\section{Some Ethical Issues in Marketing}

Contemporary marketing concerns include a range of managerial, consumer, and public policy issues. An exhaustive analysis of these questions is neither possible nor, arguably, necessary to serve the purpose of this discussion. However, several of each can certainly be proposed as sufficient to establish the point that CST is "up to the job" of providing moral direction to individual, corporate, and public decision making. Marketing managers today are confronted with a range of possibilities, aided by advances in technology, in product conceptualization and design, promotion, pricing, and distribution. The design and promotion of high performance versus energy efficient automobiles have implications for the environment.

The use of the Internet as a vehicle for promoting and pricing products raises questions of fairness as does the exclusion of consumers who have no Internet access. Consumer ethics must address lifestyle and product choices. Public policy makers confront questions about the impact of regulations on various sectors of society. Finally, overarching concerns exist regarding the impact of globalization on the rights of workers, the environment, and the comparative standards of living and quality of life in more and less developed economies. More detailed discussion of these issues follow.

\section{Product Design and Promotion}

Both safety and social-environmental impact are important considerations in the conceptualization, design, production, and disposal of many products. Heightened consumer interest in these issues has undoubtedly increased the attention given to them. Nonetheless, the weight given these concerns by marketers seems highly variable and not all consumers bring these concerns to the fore in their purchase decisions. Accordingly, selling and advertising messages commonly stress attributes such as speed in automobiles, the social pleasures associated with alcoholic beverages, the low cost of toys produced in low wage economies, and so on. However, in response to health and ecological concerns, marketers often stress these qualities even when their presence is debatable.

Journal of Macromarketing, Vol 29, No. 3 (September 2009): pg. 233-243. DOI. This article is @ SAGE Publications and permission has been granted for this version to appear in e-Publications@Marquette. SAGE Publications does not grant permission for this article to be further copied/distributed or hosted elsewhere without the express permission from SAGE Publications. 


\section{Promotion and Pricing}

The combination of so-called spyware or leechware and data mining, often implemented under questionable circumstances, facilitates the targeting of promotional messages and pricing practices based on individual demand propensities. First, the data that are the foundation for these practices are often obtained via deceptive practices and invasions of privacy. Second, while some may benefit from information and pricing that responds to individual needs or interests or rewards loyalty, others complain that they are subject to unwanted e-mail, "robo-calls," pop-up ads, and inflated pricing for some products and services because of their postal codes, past purchases, or the timing of transactions.

\section{Consumer Ethics}

Markets and the exchange transactions that make them operative are based on mutual trust. Unfortunately, that trust is frequently violated when obligations, implied or explicit, are ignored or violated. While it is customary to call attention to corporate violations, for example, failures to deliver promised services in a timely manner, consumers also frequently abuse the trust placed in them to pay according to promise or otherwise observe contract terms. At a more macro level, social concerns about environmental and cultural deterioration are heightened by consumer choices that increase the depletion of natural resources, add to pollution, or otherwise appear to degrade population segments or humanity in general. Some wellknown examples here are the purchase of vehicles with poor fuel consumption, the failure to take advantage of convenient recycling opportunities, forms of entertainment that inherently victimize women, and taking advantage of free riding opportunities by failing to support important cultural institutions in our communities.

\section{Public Policy and Regulation}

Satisfactory market performance requires rules that govern institutional structures and conduct that would otherwise result in unacceptable levels of justice and efficiency. However, such rules are often forged in a political atmosphere of conflicting interests and ideological extremes. Accordingly, a common experience is either

Journal of Macromarketing, Vol 29, No. 3 (September 2009): pg. 233-243. DOI. This article is () SAGE Publications and permission has been granted for this version to appear in e-Publications@Marquette. SAGE Publications does not grant permission for this article to be further copied/distributed or hosted elsewhere without the express permission from SAGE Publications. 
inadequate regulation or enforcement or, on the other hand, regulations that unreasonably limit freedom and/or can only be enforced at a cost that far outweighs any benefit. Market forcescompetition and information-alone are often sufficient to control situations that might disadvantage some buyers or sellers. However, social and environmental impacts that, for the most part, lie beyond the predictable influence of individual buyers and sellers because of limited information or personal interest may call for governmental intervention. However, zeal to prevent abuses can also lead to "regulatory failure"-policy strategies and enforcement mechanisms that unduly limit innovation, cost too much, or ignore alternative approaches that might be more effective or less costly.

\section{Market Globalization}

The geographic expansion and integration of markets across the globe have brought opportunities and advantages to many in the form of access to new or better products, lower prices, and potential demand that would otherwise be unavailable. These advantages, however, are often "purchased" at the expense of employment where sources of supply emigrate to new suppliers characterized by poor working conditions and environmental abuse. Globalization has also heightened concerns about quality controls and product safety in regimes where regulation is weak or even nonexistent and short-term opportunism seems to dominate business strategy.

\section{Applying CST to Marketing Issues}

The juxtaposition of the major themes in CST and marketing issues outlined above are displayed in table 1 . The letters in each cell refer to the following comments regarding the kind of direction CST affords to individuals, firms, and public policy makers. CST is not put forward as the final solution to problems in the realms specified below. Rather, it offers a set of principles to be consulted by marketing decision makers of good will when deciding how to resolve questions where ethical implications are present. In the aggregate, these connections to CST provide a core of "A to $Z$ " normative guidelines for ethical marketing (Laczniak and Murphy 2006).

Journal of Macromarketing, Vol 29, No. 3 (September 2009): pg. 233-243. DOI. This article is () SAGE Publications and permission has been granted for this version to appear in e-Publications@Marquette. SAGE Publications does not grant permission for this article to be further copied/distributed or hosted elsewhere without the express permission from SAGE Publications. 


\section{Product Design and Promotion}

A. Marketers should place a high priority on safety and refrain from promotions that take advantage of information asymmetries and motivations that reflect psychological insecurity or immaturity. As an example of an actual response to this issue, Gillette appointed a vice president for product integrity, who was given veto power over new product ideas.

B. Marketers ought to take seriously their obligations to guard the interests of consumers, while honoring the rights of both companies and consumers to make choices that are as free from coercion or limits as practicable. Consumer hotlines and warranty policies that provide for replacement or repair of products that fail, even beyond express provisions in the product guarantee, exemplify the observance of those obligations.

C. Marketers should consider the needs of low-and moderate-income consumers, the elderly consumers, and those with physical handicaps and refrain from questionable promotions and finance schemes that target disadvantaged consumers. Retailers that maintain operations in low-income neighborhoods meet these needs. Advertisers that refrain from targeting vulnerable populations with promotions requiring ethical analysis are actualizing these concerns. (Of course, some products cannot stand up to objective scrutiny and might not be launched in the first place.)

D. Marketers need to balance legitimate interests in controlling operating costs against the equally legitimate interests of channel members and their families in protecting stable employment, compensation sufficient to support a decent family life, and a safe workplace. Problems posing questions about balancing conflicting interests may sometimes best be solved through consultation and efforts to expand the domain of options under consideration. Employees or key dealers might be willing to trade off current demands for some ownership interest in a supplier. More generally, treating these key business constituents as partners, rather than adversaries, is likely to lead to more cooperative

Journal of Macromarketing, Vol 29, No. 3 (September 2009): pg. 233-243. DOI. This article is @ SAGE Publications and permission has been granted for this version to appear in e-Publications@Marquette. SAGE Publications does not grant permission for this article to be further copied/distributed or hosted elsewhere without the express permission from SAGE Publications. 
solutions to operating problems that are, in any event, ones that are shared.

E. Marketers should consider the global impact of their operations and recognize obligations to balance the impact of strategies on workers, consumers, and other stakeholders in the various regions where they do business. Businesses that make a serious effort to check on Third World contractors' labor and environmental practices, especially those sellers who work with independent nongovernmental organizations (NGOs) to certify vendor claims, are fulfilling this demand.

F. Marketers need to recognize environmental obligations in design and promotion decisions that affect ecological considerations, for example, energy efficiency, plant and vehicle emissions, and recyclability of products and parts. For example, companies increasingly impose a "green criterion" in their product development, for example, their logistics strategies and new product proposals now require response to these broader obligations.

\section{Promotion and Pricing}

G. Marketers should refrain from promotions and pricing schemes that take advantage of information asymmetries and/or buyer weaknesses. The development of an advertising campaign in a highly competitive media environment is a significant challenge under this principle, given the temptation to "push the envelope" with respect to acceptability regarding what is misleading or deceptive, pornographic, or ethnically stereotypical. As a practical matter, however, unreasonable scruples applied to these prospects might well put advertisers-and agencies-out of the race. One organizational response to this problem is to create an ombudsman system whereby agency and advertiser employees can raise concerns and have them adjudicated by a party or panel that is disinterested in the outcome but is sensitive to both economic and ethical concerns. Of course, in some cases, the implication of this procedure for advertising agencies is a lost client or declined business.

Journal of Macromarketing, Vol 29, No. 3 (September 2009): pg. 233-243. DOI. This article is @ SAGE Publications and permission has been granted for this version to appear in e-Publications@Marquette. SAGE Publications does not grant permission for this article to be further copied/distributed or hosted elsewhere without the express permission from SAGE Publications. 
H. Marketers should avoid programming that threatens family or community integrity while emphasizing strategies that are responsive to local needs. For instance, in today's markets, electronic games have great potential for family-oriented recreation as well as for activities that simulate sociopathological conduct. Thus, marketers should take measures to communicate Entertainment Software Rating Board (ESRB) ratings to all buyers and encourage enforcement of the same with their distributors.

I. Marketers must recognize special obligations to children and adolescents as well as those whose addictions may be stimulated by promises and images projected over the World Wide Web. This concern goes to product suitability as well as to ageappropriate promotion content and media.

\section{Consumer Ethics}

J. Consumers should make choices that meet authentic needs while avoiding products, behaviors, and lifestyles that may endanger others. Here, "risk to others" as a choice criterion would be applied to recreational purchases such as hunting weapons and vehicles, especially those targeted to young or inexperienced users.

$\mathrm{K}$. Consumers must recognize their responsibilities to marketers and others that protect the integrity of marketing transactions and relationships while honoring freedom of choice. Timely payments and truth telling in applications for warranty relief fulfill such ethical obligations of consumers.

L. Consumers ought to choose products and services and disposal methods that protect environmental sustainability, for example, favoring energy efficiency, renewable resources, and recycling. Here again, this implies the application of a "green criterion" when selecting, using, and disposing of products with environmental implications.

Journal of Macromarketing, Vol 29, No. 3 (September 2009): pg. 233-243. DOI. This article is C SAGE Publications and permission has been granted for this version to appear in e-Publications@Marquette. SAGE Publications does not grant permission for this article to be further copied/distributed or hosted elsewhere without the express permission from SAGE Publications. 


\section{Public Policy and Regulation}

M. Policy makers should adopt regulatory strategies that preserve, insofar as possible, freedom of individual choice, while recognizing the value of improving economic opportunities and health and safety for all persons. Policies that internalize social costs and benefits or facilitate consumer information may better serve these concerns than those that prohibit or mandate, for example, product content or designs. Some may argue, for example, that contemporary playground equipment safety standards have gone too far in protecting children from the risk of injury-to the point that children are overprotected and that "play value" has been eliminated from these products.

N. Policy makers must meet their obligations to serve the common good, irrespective of variations in political and economic power across constituencies, refraining from corrupt practices (e.g., bribery or extortion), while fostering the development and maintenance of institutions and policies that advance individual liberty. Requirements for transparency regarding provenance and content, readable use instructions, and information about product risks generally advance the welfare of all while maintaining freedom of choice.

O. Policy makers ought to recognize obligations to families and communities whose interests may be lost in regulatory strategies that do not honor the principle of subsidiarity. While social and ethical issues that arise in marketing have a degree of universality about them, solutions need to recognize local conditions. An advertising concept appropriate for adults (e.g., erectile dysfunction remedies) may be inappropriate in television, print, or Internet media with a significant juvenile audience.

P. Policy makers need to recognize special obligations to protect the welfare of the poor, disadvantaged minorities, youth, elderly people, and others whose ability to navigate and take advantage of complex markets might otherwise be compromised. The appropriate standard of care regarding adequate information where vulnerable consumers are concerned may not be "the permission has been granted for this version to appear in e-Publications@Marquette. SAGE Publications does not grant permission for this article to be further copied/distributed or hosted elsewhere without the express permission from SAGE Publications. 
NOT THE PUBLISHED VERSION; this is the author's final, peer-reviewed manuscript. The published version may be accessed by following the link in the citation at the bottom of the page.

reasonable adult" but a credulous teenager or an older adult approaching dementia.

Q. Policy makers ought to balance responsibilities to workers and consumers while protecting the dignity of both. In many respects, this concern is resolved by recognizing that workers are consumers; the apparent conflict is contrived, not real. More generally, this obligation calls for balancing interests when cost or demand level factors are in play.

R. Policy makers should refrain from policies that unnecessarily serve the interest of only some segments of society, taking into account both local and global interests. While the current trade situation might be adverse to certain domestic production interests, economic isolationism is probably a less appropriate approach to serving those interests than less radical adjustments to terms of trade that retain advantages for foreign and consumer interests.

S. Policy makers ought to observe the interests of future generations in regulatory strategies that protect the natural environment. Many regulatory questions confront conflicting environmental and economic (especially employment) concerns. Job preservation or growth is desirable, for example, in the forest products industry, which has been hard hit by environmental protection policies that control production quantities and methods. Nonetheless, the environmental devastation that occurred as a result of indiscriminate harvesting and processing practices in the nineteenth and early twentieth century must not return. Publicly supported research and policy experimentation might lead to results that would reduce that conflict.

\section{Globalization}

T. Marketers and policy makers need to respect the interests of all persons, refraining from merely taking advantage of economic, educational, and other circumstances, treating some as only a means of production or economic success. In response to this

Journal of Macromarketing, Vol 29, No. 3 (September 2009): pg. 233-243. DOI. This article is @ SAGE Publications and permission has been granted for this version to appear in e-Publications@Marquette. SAGE Publications does not grant permission for this article to be further copied/distributed or hosted elsewhere without the express permission from SAGE Publications. 
concern, the impoverished workers and consumers in developing countries are to be considered the moral equivalents of domestic consumers and workers. This is a very challenging standard, particularly because a strong argument can be made for "taking care of our own" in both political and business contexts. However, it follows that efforts must be made to advance or protect the interests of those "others." If import standards are not thoughtfully drafted, they unnecessarily have an adverse impact on foreign producers (often the poorest poor) and provide little or no incremental protection for domestic consumers.

U. Marketers and policy makers ought to provide for participative mechanisms in decisions that affect families and communities and, in less developed regions, attempt to meet the needs of families and communities in such basic areas as health care, education, and housing. Marketers are generally quite good at using survey methodologies to inform product and promotion decisions. Yet there may be little consultation with those most directly affected by foreign investment decisions, particularly where trade-offs among social needs must be considered. Before committing to "best available technology" with respect to pollution control or energy consumption, the prospect that local families have desperate needs for potable water or a working waste disposal system might be considered and weighed. Simply put, global marketing efforts must better represent the interests of impoverished, vulnerable consumers and advocate for their concerns when they are unable to effectively represent themselves.

V. Marketers must recognize special responsibilities to both individuals and communities in settings where policies and regulations are weak or nonexistent and refrain from participation in corrupt practices and human rights violations that appear to be inherent in such settings. This recognition implies that cultural relativism is inappropriate as guidance for behavior. Corrupt practices and abuses do not suddenly become proper by occurring in nations where they are not outlawed or because legal restrictions against them are not enforced.

Journal of Macromarketing, Vol 29, No. 3 (September 2009): pg. 233-243. DOI. This article is @ SAGE Publications and permission has been granted for this version to appear in e-Publications@Marquette. SAGE Publications does not grant permission for this article to be further copied/distributed or hosted elsewhere without the express permission from SAGE Publications. 
NOT THE PUBLISHED VERSION; this is the author's final, peer-reviewed manuscript. The published version may be accessed by following the link in the citation at the bottom of the page.

W. Marketers, policy makers, and consumers must accept recognize obligations to protect and advance the interests-liberty and welfare-of the poor, minorities, women, and rural populations in settings where these interests are exploited, ignored, or given only lip service. As it happens, a global economy confers major advantages in societies where economic and social divisions may be the greatest. However, whether marginalized members of those societies receive those benefits depends heavily on whether powerful local public and business officials recognize their needs in distributing those benefits. This is a call to fairness for those local officials and, in many cases, a call for imposing distribution requirements (wage, working conditions, and social welfare programs) in terms of trade and economic aid by political and economic participants in the global marketplace from more advanced societies.

X. Marketers should foster, nay require, healthy working conditions and adequate wages in jurisdictions where these values are often abused, especially when labor and other subcontractors use the shield of privacy to protect practices that would otherwise be an embarrassment to their customers and clients. As suggested previously, this concern calls for investigation and sanctions in situations where abuses are likely. Companies should work with an NGO, independent from the marketing organization, to certify that production practices meet acceptable standards; this adds to the assurance and credibility that these conditions of labor market justice are met.

Y. Marketers, policy makers, and consumers ought to observe the common interests of humanity across economic, social, and geographic groups. A prominent concern in this regard is the practice of selling goods (i.e., product dumping) in Third World markets that are prohibited in North America and Western Europe because of their impact on health, safety, or the environment.

Journal of Macromarketing, Vol 29, No. 3 (September 2009): pg. 233-243. DOI. This article is @ SAGE Publications and permission has been granted for this version to appear in e-Publications@Marquette. SAGE Publications does not grant permission for this article to be further copied/distributed or hosted elsewhere without the express permission from SAGE Publications. 
Z. Marketers and policy makers need to take account of the interests of future generations and the environment in all settings where those interest might otherwise be ignored, refraining from practices that are permitted because of lax or nonexistent regulations. Procurement of forest, agricultural, and animal products that result from wholesale deforestation seems to raise a concern in this regard.

\section{Concerns and Limitations}

In considering CST as a source of guidance for resolving managerial and public policy questions in marketing, the validity and appropriateness of this guidance, particularly as the context of these questions is most often nonecclesiastical, should be properly weighed.

A reasonable first concern is the proper standing of CST relative to longstanding and/or nonreligious moral traditions. It has been demonstrated here that CST is generally consistent with various philosophical ethical frameworks, for example, rights and duties, stakeholder claims, "justice as fairness," and social contract theories. It must be noted, however, that this consistency is operative at the practical level, not precisely in the fullness of its philosophical roots. Alford (2006) offers a compelling argument for these philosophical differences. Despite the etymological validity of that argument, however, there is often little patience among managers and public policy makers for philosophical discourse and a deep desire for practical guidance. As the authors noted at the outset of the article, they see this particular religious perspective and other perspectives converging in addressing problems of contemporary importance.

(Some might question the universality of the CST tradition in light of conflicting views about issues that seem to separate Church and secular perspectives and have captured popular attentionabortion, women in the priesthood, and so on. This is certainly not the venue for a detailed discussion of such issues, which lie outside the marketing domain. Moreover, the authors are not bioethicists, ecclesiologists, or canon lawyers-experts who might take these questions on with authority. The authors' more limited approach to these issues lies in the belief that, as in real marketing situations, the

Journal of Macromarketing, Vol 29, No. 3 (September 2009): pg. 233-243. DOI. This article is (C) SAGE Publications and permission has been granted for this version to appear in e-Publications@Marquette. SAGE Publications does not grant permission for this article to be further copied/distributed or hosted elsewhere without the express permission from SAGE Publications. 
principles are applicable but need to be considered in conjunction with other pertinent principles and criteria.)

A ranging review of the CST tradition also is likely to unearth radical criticisms of circumstances to be found in various markets and parts of the world as well as radical solutions for the social and economic problems they identify. This is particularly the case when the authors of these criticisms and proposals write without ecclesiastical authority. Some of the calls by liberation theologians in the 1970 s and 1980s for the widespread nationalization of corporate assets would be a specific example of such excesses (see, e.g., Gutie' rrez 1988). At the opposite extreme, one can find arguments that the principles of dignity and the common good require a more robust degree of subsidiarity, i.e., individual autonomy is best served in markets in which governments play an extremely limited role (see, e.g., Novak 1993). Whatever their merits, such critiques and proposals are unlikely to find wide acceptance among those with the authority and responsibility for uncovering and implementing pragmatic, corrective solutions. Relative to the evolution of CST during the past two decades, the Church has both denounced the more extreme positions of the liberationist perspective and, subject to a concern for the common good, espoused the role of private property and markets in economic affairs.

Considered as a whole, however, CST offers a balanced and nuanced understanding of the legitimate conflicts between present and future as well as individual and community interests extant in many important socioeconomic dilemmas. The guidance provided, as noted by Dennis McCann (1997), is both religious and publicly accessible, "theologically grounded as well as publicly argued." To paraphrase the remarks of a reviewer of an early draft of this article, CST is proposed as both universal and essential to moral and spiritual order. While the Catholic social tradition is deeply theological and spiritual, it is not merely sectarian. It speaks to all people of good will, yet is not proposed as having a monopoly on the good. This tradition connects faith with reason and is commonly expressed in terms of natural law. It expresses a uniquely coherent, consistent, yet dynamic set of standards that bear within themselves a compelling rationale: to act out of one's best and most noble instincts, with the intention of serving

Journal of Macromarketing, Vol 29, No. 3 (September 2009): pg. 233-243. DOI. This article is (C) SAGE Publications and permission has been granted for this version to appear in e-Publications@Marquette. SAGE Publications does not grant permission for this article to be further copied/distributed or hosted elsewhere without the express permission from SAGE Publications. 
the finest, most noble qualities in others. This tradition has confidence that its particular teachings and principles can be presented and placed in dialogue with the world in a way that is intelligible and accessible to people of all backgrounds and cultures, religious or secular-because of our common humanity. That is, it captures what is necessary for all people to live in harmony.

Moreover, the philosophical character of the tradition provides resources for faith-based principles of morality to be expressed in more reason-based terms that will resonate with the wide range of people represented in the marketplace. (This is not to imply that CST is a superior, ethical theory because it is religiously inspired. The authors' contention is, rather, that it captures succinctly and usefully many of the moral sentiments reflected in other philosophical moral theories.)

Significantly, CST leaves the task of solving specific problems and dilemmas to the informed consciences at work in particular situations in the private and public sectors. As a reviewer of an early draft of this manuscript noted, "Catholic social principles ... do not guarantee competence. ... Principles alone do not provide blueprints or technical solutions, nor are they meant to. They point the direction, but they do not show the way. There is no Catholic cookbook on how to advertise in non-manipulative but creative and effective ways." Such problems require moral and particular judgments, hopefully enlightened, regarding problems having varying circumstances and implications by the decision makers involved. While disputes about solutions are predictable, the authors' point is to advocate bringing the light of this set of moral principles (as a complement to traditional business/economic thinking) to bear on marketing problems. While not proposed here as a replacement for sound business judgment, CST provides an ethical framework for those public and private decisions that foster human flourishing, including both those institutions and practitioners that serve that less ambiguous end.

CST reflects a tradition in moral theology that dates at least to biblical sources. Yet the relevance of that tradition to modern economies has only been explored and explained during the past century or so and applications to marketing problems (as opposed to labor relations) have been minimal. Thus, bringing insights from this

Journal of Macromarketing, Vol 29, No. 3 (September 2009): pg. 233-243. DOI. This article is @ SAGE Publications and permission has been granted for this version to appear in e-Publications@Marquette. SAGE Publications does not grant permission for this article to be further copied/distributed or hosted elsewhere without the express permission from SAGE Publications. 
particular moral theology to bear on macromarketing problems seems both novel and worthwhile.

A related question is whether or to what extent marketing managers who are also Catholics-or those from other faith traditions-are familiar with and follow these CST principles. Many Catholic managers may be relatively uninformed about CST partly because it speaks to political, public policy, and economic issues that many clergy are reluctant to address from the pulpit because of the American tradition of the separation of Church and State. However, informed Catholic managers, who take their faith life seriously and believe their religion should influence their professional lives, are obligated at minimum to give serious reflection to the propositions that comprise CST. As the prescriptions shaping CST are generally consistent with the exhortations of other faith traditions that compose the Abrahamic religions, they are intended for all men and women of goodwill who accept such values as instrumental to their vocations as managers. However, it should also be understood that in developed, Western cultures, these faith values are most likely to apply indirectly via the consciences of individual managers. In some other cultures, for example, in regions where Islamic fundamentalists have their religious beliefs reflected in theocratically derived law, comparable principles are imposed by the State (Saeed, Ahmed, and Mukhtar 2001).

In conclusion, CST makes four important contributions in resolving ethical questions in marketing:

1 CST assists in the resolution of ethical dilemmas at both the micro (personal and organizational) and macro (institutional or system) levels.

2 CST demarcates a common ground for helping resolve marketing conflicts that persist in applications of the principal secular, teleological, and deontological moral philosophies espoused in business ethics. That commonality lies in the goal of advancing the welfare of humanity, which has both individual and social or community dimensions.

3 Insofar as an understanding of religious norms are critical to understanding economic institutions and behaviors in nations across the world (e.g., Mittelstaedt 2002) and given that most

Journal of Macromarketing, Vol 29, No. 3 (September 2009): pg. 233-243. DOI. This article is @ SAGE Publications and permission has been granted for this version to appear in e-Publications@Marquette. SAGE Publications does not grant permission for this article to be further copied/distributed or hosted elsewhere without the express permission from SAGE Publications. 
religious traditions agree with the themes advanced by CST, it offers a worthy basis for the development of a global business and marketing ethos because it embodies the religious/cultural norms underlying most societies.

4 CST meets the test of rationality insofar as it is consistent with the natural law, that is, is based on a coherent and broadly accepted understanding of the nature of humanity.

The conclusion reached on the basis of the authors' analysis is that Catholic social teaching offers guidance that goes substantially beyond that of a denominational morality. It usefully provides a set of principles-universal and coherent-for solving important contemporary problems in marketing having prominent social implications. Marketers, public policy makers, and consumers concerned with discharging their ethical responsibilities can benefit from following these principles. Academics testing or articulating the efficiency, efficacy, and ethicality of marketing systems can also gain from the general insights provided by Catholic social teaching.

\section{Note}

1. "The conventional rendering is 'Catholic social thought' and 'Catholic social teaching' rather than 'Roman Catholic ...." The other branches of the Catholic religion-Greek, Ruthenian, Maronite, Coptic-have their own rituals and hierarchy but under the Pope, who is responsible for the most important documents cited here; others are mainly derivative, intended to meet the needs of particular nations, for example, those from the US bishops.

\section{Biographies}

Thomas A. Klein is professor of marketing emeritus in the College of Business Administration at the University of Toledo, 2801 West Ban-croft Street, Toledo, $\mathrm{OH} 43606$; phone: (419) 530-4368; fax: (419) 530-4610; email: tklein2@utoledo.edu. He is also adjunct professor of business administration at TUI University. His research and teaching specialties are business and marketing ethics, marketing institutions and systems, and strategic marketing.

Gene R. Laczniak is professor of marketing in the College of Business, Marquette University, Milwaukee, WI 53201; phone: (414) 288-7024; e-mail:

Journal of Macromarketing, Vol 29, No. 3 (September 2009): pg. 233-243. DOI. This article is () SAGE Publications and permission has been granted for this version to appear in e-Publications@Marquette. SAGE Publications does not grant permission for this article to be further copied/distributed or hosted elsewhere without the express permission from SAGE Publications. 
NOT THE PUBLISHED VERSION; this is the author's final, peer-reviewed manuscript. The published version may be accessed by following the link in the citation at the bottom of the page.

gene.laczniak@marquette.edu. His research and teaching focuses on business ethics, corporate social responsibility, and marketing strategy.

\section{References}

Alford, Helen. 2006. Stakeholder theory. In The good company: Catholic social thought and corporate social responsibility in dialogue. Rome, Italy: Pontifical University of St Thomas (October 7). http://www.stthomas.edu/cathstudies/cst/conferences/thegoodcompa ny/Finalpapers/Alford\%2007.10.06\%209.00.pdf (accessed March 22, 2008).

Aristotle, ed. 1985. Nicomachean ethics. Trans. Terrence Irwin. Indianapolis, IN: Hacket Publishing Company.

Compendium of the social doctrine of the church. 2005. Rome, Italy: Pontifical Council for Justice and Peace. http://www.vatican.va/roman_curia/pontifical_councils/justpeace/ documents/rc_pc_justpeace_doc_20060526_compendio-dottsoc_en.html (accessed March 28, 2008).

DeBerri, Edward P., James E. Hug, Peter J. Henriot, and Michael J. Schultheis. 2003. Catholic social teaching: Our best kept secret. 4th ed. New York: Orbis Books.

Donaldson, Thomas, and Thomas W. Dunfee. 1999. Ties that bind: A social contract approach to business ethics. Boston: Harvard University Press.

Elkington, John. 1998. Cannibals without forks: The triple bottom line in the 21st century. London: New Society Publishers.

Ethics in advertising. 1997. Rome: Pontifical Council for Social Communications.

Ethics in Internet. 2002. Rome: Pontifical Council for Social Communications.

Freeman, R. Edward. 1984. Strategic management. Marshfield, MA: Pitman.

Freeman, R. Edward, Jeffrey S. Harrison, and Andrew C. Wicks. 2007. Managing for stakeholders: Survival, reputation, and success. New Haven, CT: Yale University Press.

Gutie' rrez, Gustavo. 1988. A theology of liberation: history, politics, and salvation. Maryknoll, NY: Orbis Books.

Journal of Macromarketing, Vol 29, No. 3 (September 2009): pg. 233-243. DOI. This article is @ SAGE Publications and permission has been granted for this version to appear in e-Publications@Marquette. SAGE Publications does not grant permission for this article to be further copied/distributed or hosted elsewhere without the express permission from SAGE Publications. 
NOT THE PUBLISHED VERSION; this is the author's final, peer-reviewed manuscript. The published version may be accessed by following the link in the citation at the bottom of the page.

Kant, Immanuel. 1787. Grounding for the metaphysics of morals. Third edition. Translated by Richard Ellington, Classic Series (1993). Indianapolis, IN: Hackett Publishing.

Klein, Thomas A. 1987. Prophets and profits-A macromarketing perspective on Economic justice for all: Catholic social teaching and the U.S. economy. Journal of Macromarketing 7:59-77.

Laczniak, Gene R. 1998. Reflections on the 1997 Vatican statements regarding ethics in advertising. Journal of Public Policy \& Marketing $17: 320-24$.

Laczniak, Gene R. 1999. Distributive justice, Catholic social teaching, and the moral responsibility of marketers. Journal of Public Policy \& Marketing 18:125-9.

Laczniak, Gene R., and Patrick E. Murphy. 2006. Normative perspectives for ethical and socially responsible marketing. Journal of Macromarketing 26:154-77.

Lovelock, James. 1979. Gaia-A new look at life on earth. London, UK: Oxford University Press.

MacIntyre, Alasdair. 2007. After virtue. 3rd ed. Notre Dame, IN: University of Notre Dame Press.

Massaro, Thomas. 2005. On work and markets. America, June 6-13:11-3.

McCann, Dennis. 1997. Catholic social teaching in an era of economic globalization. Business Ethics Quarterly 7:57-71.

McMahon, Thomas F. 1989. Religion and business: Concepts and data. Chicago Studies 28:3- 15.

Mittelstaedt, John D. 2002. A framework for understanding the relationships between religions and markets. Journal of Macro-marketing 22:6-18.

National Conference of Catholic Bishops. 1996. A Catholic frame-Conference. http://www.usccb.org/sdwp/international/ACatholic FrameworkforEconomicLife.pdf (accessed April 4, 2009).

Naughton, Michael J., Helen Alford, and Bernard Brady. 1995. The common good and the purpose of the firm: A critique of the shareholder and stakeholder models from the Catholic social tradition. Journal of Human Values 1:221-37.

Novak, Michael. 1993. The Catholic ethic and the spirit of capitalism. New York, NY: Free Press.

Journal of Macromarketing, Vol 29, No. 3 (September 2009): pg. 233-243. DOI. This article is (C) SAGE Publications and permission has been granted for this version to appear in e-Publications@Marquette. SAGE Publications does not grant permission for this article to be further copied/distributed or hosted elsewhere without the express permission from SAGE Publications. 
NOT THE PUBLISHED VERSION; this is the author's final, peer-reviewed manuscript. The published version may be accessed by following the link in the citation at the bottom of the page.

Pope John XXIII. 1963. Pacem in terris (On establishing universal peace in truth, justice, charity, and liberty), April 11.

http://www.vatican.va/holy_father/john_xxiii/encyclicals/ documents/hf_j-xxiii_enc_11041963_pacem_en.html (accessed Retrieved February 16, 2008).

Pope John Paul II. 1981. Laborem exercens (On human work), September 14. http://www.vatican.va/holy_father/john_paul_ii/encyclicals/documents /hf_jp-ii_enc_14091981_laborem-exercens_en.html (accessed February 16, 2008).

Pope John Paul II. 1987. Sollicitudo rei socialis (On the social concerns of the Church), December 30. http://www.vatican.va/holy_father/john_paul_ii/encyclicals/documents /hf_jp-ii_enc_30121987_sollicitudo-rei-socialis_en.html (accessed February 16, 2008).

Pope John Paul II. 1991. Centesimus annus (On the hundredth anniversary of Rerum Novarum), May 1, http://www.vatican.va/holy_father/john_paul_ii/encyclicals/documents /hf_jp-ii_enc_010519 91_centesimus-annus_en.html (accessed April 4, 2009).

Pope Leo XIII. 1891. Rerum novarum (On capital and labor), May 15. http://www.vatican.va/holy_father/leo_xiii/encyclicals/documents/hf_I -xiii_enc_15051891_rerum-novarum_en.html (accessed February 16, 2008).

Pope Pius XI. 1931. Quadragesimo anno (On reconstructing the social order), May 15. http://www.vatican.va/holy_father/pius_xi/encyclicals/documents/hf_ p-xi_enc_19310515_quadragesimo-anno_en.html (accessed February $17,2008)$.

Rawls, John. 1971. A theory of justice. Cambridge, MA: Belknap Press.

Ross, William D. 1930. The right and the good. Oxford, UK: Clarendon Press.

Saeed M., Z. U. Ahmed, and S.-M. Mukhtar. 2001. International marketing ethics from an Islamic perspective: A value-maximization approach. Journal of Business Ethics 32:127-42.

Sharing Catholic social teaching: Challenges and directions. 1999. Washington, DC: United States Conference of Catholic Bishops.

Journal of Macromarketing, Vol 29, No. 3 (September 2009): pg. 233-243. DOI. This article is (C SAGE Publications and permission has been granted for this version to appear in e-Publications@Marquette. SAGE Publications does not grant permission for this article to be further copied/distributed or hosted elsewhere without the express permission from SAGE Publications. 
NOT THE PUBLISHED VERSION; this is the author's final, peer-reviewed manuscript. The published version may be accessed by following the link in the citation at the bottom of the page.

Tavis, Lee. 1999. Power and responsibility: Multinational managers and developing country concerns. Notre Dame, IN: University of Notre Dame Press.

United Nations' universal declaration of human rights. December 10, 1948. http://www.un.org/Overview/rights.html (accessed February 16, 2008).

\section{Appendix}

\section{Table 1: Applications of Major Themes in Catholic Social Teaching to} Selected Social Issues in Marketing

\begin{tabular}{|c|c|c|c|c|c|c|c|}
\hline Issues & $\begin{array}{l}\text { Human } \\
\text { Dignity }\end{array}$ & $\begin{array}{c}\text { Common } \\
\text { Good }\end{array}$ & $\begin{array}{l}\text { Subsidiarity } \\
\text { (Family and } \\
\text { Community) }\end{array}$ & $\begin{array}{l}\text { Option for the } \\
\text { Poor and } \\
\text { Vulnerable }\end{array}$ & $\begin{array}{l}\text { Dignity of Work } \\
\text { and Rights of } \\
\text { Workers }\end{array}$ & Solidarity & $\begin{array}{l}\text { Stewardship } \\
\text { (Care for God's } \\
\text { Creation) }\end{array}$ \\
\hline $\begin{array}{l}\text { Product design and } \\
\text { promotion }\end{array}$ & A & & B & C & D & $\mathrm{E}$ & $\mathrm{F}$ \\
\hline Promotion and pricing & G & & $\mathrm{H}$ & I & & & \\
\hline Consumer ethics & $\mathrm{J}$ & & $\mathrm{K}$ & & & & $\mathrm{L}$ \\
\hline $\begin{array}{l}\text { Public policy and } \\
\text { regulation }\end{array}$ & $\mathrm{M}$ & $\mathrm{N}$ & $\mathrm{O}$ & $P$ & $\mathrm{Q}$ & $\mathrm{R}$ & $\mathrm{S}$ \\
\hline Globalization & $\mathrm{T}$ & $\mathrm{U}$ & V & W & $\mathrm{X}$ & $\mathrm{Y}$ & Z \\
\hline
\end{tabular}

Journal of Macromarketing, Vol 29, No. 3 (September 2009): pg. 233-243. DOI. This article is @ SAGE Publications and permission has been granted for this version to appear in e-Publications@Marquette. SAGE Publications does not grant permission for this article to be further copied/distributed or hosted elsewhere without the express permission from SAGE Publications. 